\title{
Kriminalitet u ozračju pandemije bolesti COVID-19 u Hrvatskoj
}

\author{
Ksenija Butorac \\ Ministarstvo unutarnjih poslova, Visoka policijska škola, Zagreb, Hrvatska \\ e-mail: ksenija.butorac@gmail.com
}

\section{Davor Solomun}

Ministarstvo unutarnjih poslova, Visoka policijska škola, Zagreb, Hrvatska e-mail:dsolomun@fkz.hr

SAŽETAK Ovo istraživanje obuhvaća analizu ukupnog kriminaliteta s detaljnim uvidom u opći ili konvencionalni kriminalitet u petogodišnjem razdoblju prije nastupanja pandemije bolesti COVID-19 (2015. - 2019.) u odnosu na godinu pandemije (2020.). Empirijska analiza temelji se na sekundarnim podacima registriranih kaznenih djela i prekršaja, za tu svrhu zatraženim i dobivenim od Ministarstva unutarnjih poslova Republike Hrvatske, što predstavlja posredno mjerenje kriminaliteta na određenom području (Palmer, 2020.). Problem eksplorativnog istraživanja u ovom radu stjecanje je novih spoznaja o eventualnim promjenama u opsegu, strukturi i dinamici kriminaliteta te tipologiji i obrascima policijski registriranih kaznenih djela i prekršaja u pandemijskom kriznom razdoblju, a u odnosu na prethodno petogodišnje razdoblje u Hrvatskoj. Dobiveni rezultati promatraju se kroz primjenjivost teorijskih koncepata ekološke kriminologije u objašnjenju promjene trendova u tipologiji i obrascima kriminalnog i devijantnog ponašanja. Smisao istraživanja bio je prikazati kako novonastala pandemijska svakodnevica utječe općenito na pokretljivost ukupnog kriminaliteta, ali i na specifične segmente kriminaliteta na području Republike Hrvatske i pojedinih policijskih uprava.

Ključne riječi: COVID-19, opći kriminalitet, imovinski delikti, delikti nasilja, ekološka kriminologija. 


\section{Uvod}

Početkom 2020. godine globalna zajednica u cjelini i svaka država pojedinačno zaokupljena je višedimenzionalnom prirodom pandemijske viktimizacije izazvane virusom SARS-CoV-2. Pandemija podrazumijeva eksplozivnost, prenosivost i težinu zaraze virusnom bolesti (Morens, Folkers i Fauci, 2009.), ali ne proizvodi isključivo egzistencijalnu zdravstvenu prijetnju. $S$ obzirom na to da virusna pandemija rezultira povredom ljudskih prava (General Assembly Resolution 40/34; United Nations, 1985.) te nizom fizičkih, ekonomskih, socijalnih i psiholoških učinaka na pojedinca i društvo, Cohen-Louck i Inna Levy (2020.) koriste pojam „viruizam“ praveći analogiju s terorizmom, koji, unatoč postojećim razlikama u pogledu etiologije, nositelja i naravi ugroze, također evocira visoku razinu percepcije neizvjesnosti i prijetnje te dovodi do enormnih financijskih, društvenih i psihosocijalnih posljedica po pojedinca i društvo. Posljednja istraživanja procjenjuju kako je tzv. pandemijsko zatvaranje generiralo visoke razine nezaposlenosti, povećalo inflaciju i znatno smanjilo kupovnu moć građana, što je pridonijelo ekspanziji siromaštva u općoj populaciji (Estrada, 2020.), slično posljedicama nastalim zbog štetnih ekonomskih učinaka terorizma na društvo (Institute for Economics and Peace, 2017.).

Kod fenomena terorizma i viruizma posljedice nisu nužno njihovi izravni učinci u obliku fizičkih ozljeda ili smrtnih ishoda, već je značajna i nuspojava straha i ugroze koje oba fenomena izazivaju u široj javnosti. Iako se opseg ograničenja razlikovao ovisno o državi, težini i brzini širenja pandemije (Lee, Chiew i Khong, 2020.; Watkins, 2020.), najveći dio svjetske populacije bio je ili ostao u karanteni tijekom više mjeseci (Kaplan, Frias i McFall-Johnson, 2020.). Građani su bili prisiljeni mijenjati način života, primjerice nisu smjeli napustiti svoje domove, putovati na posao, odvesti djecu u vrtić ili školu, posjećivati javne parkove, restorane i trgovačke centre jer su bili zatvoreni. Ta su ograničenja bila de iure nalozi vladinih tijela, a nepridržavanje izrečenih mjera normiranih zakonima dovelo je do kažnjavanja za prekršaj ili kazneno djelo. Nametnute restriktivne mjere ometale su svakodnevnu rutinu u privatnom i javnom životu te više ili manje paralizirale društveni prostor i pojedince induciranjem osjećaja nesigurnosti, stresa, tjeskobe, depresije i bespomoćnosti zbog gubitka bliskih osoba (Sun i sur., 2020.; Qiu i sur., 2020.)

Na taj način stvoreni su rizici i prijetnje, a proturječni su podaci nedvojbeno kreirali stanovitu konfuziju i neslaganje u društvu. Time su utjecali na opće sigurnosno stanje i odnos građana prema sigurnosnim mehanizmima koje su represivna tijela diljem svijeta provodila tijekom 2020. godine. Mnoge su vlade poduzele hitne mjere kako bi zaštitile svoje stanovništvo i usporile širenje virusa. Takve radnje, uključujući zatvaranje, izolaciju, zabranu putovanja i pravila o fizičkoj distanci, najčešće kontrolira i provodi policija, a stvorena je i dodatna potražnja za sigurnosnim uslugama tijela za provođenje zakona. 
Početak pandemije u Republici Hrvatskoj obilježen je osnivanjem Stožera civilne zaštite od strane Vlade RH 20. 2. 2020. na prijedlog ministra unutarnjih poslova, a temeljem Zakona o sustavu civilne zaštite ${ }^{1}$ radi koordinacije svih službi u slučaju pojave koronavirusa u RH i sprečavanja širenja zaraze. Treba naglasiti kako je Stožer civilne zaštite donio čak 244 odluke o uvođenju različitih sigurnosnih mjera u razdoblju od 19. ožujka do konca 2020. godine te 406 odluka tijekom 2021. godine, od kojih se 46 odluka kontinuirano provodi do kraja 2021. godine. Zbog brojnosti, učestalosti izmjena i dopuna te redundantnosti sadržaja predmetnih odluka važećih za nacionalnu i regionalne razine, a radi uže kontekstualizacije istraživanja kriminaliteta u Republici Hrvatskoj prije i tijekom pandemijske krize, autori smatraju relevantnim izdvojiti sljedeće odluke o sigurnosnim mjerama koje su bile na snazi tijekom 2020. godine s naznakom datuma donošenja ${ }^{2}$ : Odluka o privremenoj zabrani prelaska preko graničnih prijelaza Republike Hrvatske (19. ožujka 2020.) Odluka o mjerama ograničavanja društvenih okupljanja, rada u trgovini, uslužnih djelatnosti i održavanja sportskih $i$ kulturnih dogadanja (19. ožujka 2020.); Odluka o uvodenju nužne mjere posebne organizacije rada epidemiološke službe i posebnih epidemioloških mjera vezanih uz virus SARS-Cov-2 za vrijeme proglašene epidemije bolesti COVID19 (23. ožujka 2020.); Odluka o stavljanju izvan uporabe dječjih igrališta i otvorenih sportskih igralista (20. ožujka 2020.); Odluka o privremenoj obustavi javnog prometa (21.ožujka 2020.); Odluka o mjeri strogog ograničavanja zadržavanja na ulicama i drugim javnim mjestima (21. ožujka 2020.); Odluka o radnom vremenu trgovina (21. ožujka 2020.); Odluka o zabrani napustanja mjesta prebivalista i stalnog boravka u Republici Hrvatskoj (23. ožujka 2020.); Odluka o izmjeni i dopuni Odluke o zabrani napustanja mjesta prebivalista i stalnog boravka u Republici Hrvatskoj (1. travnja 2020.); Odluka o privremenoj zabrani prelaska preko graničnih prijelaza Republike Hrvatske (30. lipnja 2020.); Odluka o nužnoj mjeri obveznog korištenja maski za lice ili medicinskih maski za vrijeme trajanja proglašene epidemije bolesti COVID-19 (10. srpnja 2020.); Odluka o nužnim mjerama za organizaciju okupljanja na kojima je prisutno više od sto sudionika za vrijeme trajanja proglašene epidemije bolesti COVID-19 (10. srpnja 2020); Odluku o nužnoj mjeri ograničavanja radnog vremena ugostiteljskih objekata iz kategorije "Barovi» (13. kolovoza 2020.); Odluka o nužnoj mjeri obveznog korištenja maski za lice ili medicinskih maski (12. listopada 2020.) i druge.

Sigurnosne mjere su uvedene početkom ožujka 2020. godine i postupno su se ublažavale kroz tri stupnja popuštanja tih mjera do kraja lipnja iste godine. Nakon tog razdoblja održale su se uglavnom nužne epidemiološke mjere uz uvođenje preventivne mjere cijepljenja, a potom i tzv. COVID potvrda za kategorije osoba koje su cijepljene te za one koje imaju negativan test SARS-CoV-2 ili su nedavno preboljeli bolest COVID-19.

\footnotetext{
1 Zakon o sustavu civilne zaštite, NN br. 82/2015, 118/2018 i 31/2020, NN 20/2021

2 Odluke Stožera civilne zaštite RH za sprečavanje širenja zaraze koronavirusom. Pregledano 15. 5. 2021. (https://civilna-zastita.gov.hr/odluke-stozera-civilne-zastite-rh-za-sprecavanje-sirenja-zaraze-koronavirusom/2304)
} 
Svako krizno stanje uvijek je odraz višedimenzionalnih utjecaja socioloških, psiholoških, politoloških, kriminoloških i drugih faktora. S obzirom na relativno oskudne, pretežito inicijalne rezultate inozemnih, a osobito domaćih istraživanja u području stanja i kretanja kriminaliteta u razdoblju „novog normalnog“, svrha ovog rada ispitati je odnos između devijantnih i kriminalnih ponašanja u Hrvatskoj između prethodnog petogodišnjeg razdoblja (2015. - 2019.) i referentnog razdoblja obilježenog pandemijskom krizom (2020.). Naime, početna istraživanja u svijetu, provedena tijekom 2020. i početkom 2021. godine, pokazala su sveopći drastičan pad stope ukupnog kriminaliteta u rasponu od 10 do $70 \%$, osobito općeg ili konvencionalnog kriminaliteta, $s$ manjim razlikama vezanim uz tipologiju, obrasce počinjenja kaznenih djela, prostor i vremenski okvir (npr. Felson, Jiang i Xu, 2020.; Campedelli i sur., 2020.; Ashby, 2020.b; Gerell, Kardell i Kindgreen, 2020.). Zanimljiv je silazni trend incidencije imovinskih delikata, a neočekivana je i indikativna nepromjenjivost učestalosti prijavljivanja kaznenih djela s elementima nasilja, poput obiteljskog nasilja, tjelesnih ozljeda i spolnih delikata, u odnosu na razdoblje prije pandemije (Payne i Morgan, 2020.).

Slijedom navedenog, problem eksplorativnog istraživanja u ovom je radu stjecanje novih spoznaja o eventualnim promjenama u opsegu, strukturi i dinamici policijski registriranog kriminaliteta i prekršaja u referentnom kriznom razdoblju, a u odnosu na prethodno petogodišnje razdoblje. Dobiveni rezultati promatraju se kroz primjenjivost teorijskih koncepata ekološke kriminologije u objašnjenju promjene trendova u tipologiji i obrascima kriminalnog i devijantnog ponašanja. Za potrebe istraživanja u radu se analiziraju i problematiziraju usporedni statistički pokazatelji opsega, strukture i dinamike policijski registriranog kriminaliteta i prekršaja u referentnom kriznom razdoblju, a u odnosu na petogodišnje razdoblje prije izbijanja pandemije. U užem smislu ispitani su trendovi općeg ili konvencionalnog kriminaliteta u rasponu od višeg do najnižeg stupnja društvene opasnosti.

\subsection{Primjena koncepata ekološke kriminologije}

Svjetska je zdravstvena organizacija (SZO) 30. siječnja 2020. godine do tada nepoznati koronavirus označila i nazvala SARS-CoV-2, a njime uzrokovanu bolest COVID-19 (engl. COrona Virus Disease 2019) 11. ožujka 2020. proglasila pandemijom i javno zdravstvenim hitnim stanjem globalnog međunarodnog značaja (World Health Organization, 2020.). Tim činom Svjetska zdravstvena organizacija pripisala je toj pojavi svojstvo globalne sigurnosne prijetnje.

Jedan od ključnih pokazatelja sigurnosne situacije u društvu procjena je stanja i kretanja kriminaliteta u razdoblju prije i tijekom pandemije upravo zbog nametnutih ograničenja ljudskih prava kao differentia specifica, prvenstveno uzimajući u obzir mobilnost stope kriminaliteta, tipologiju kaznenih djela i obrasce činjenja kaznenih djela. Odgovarajući teorijski okvir za istraživanje situacijskog pristupa kriminalitetu, 
socijalnog i fizičkog okruženja te okolnosti u kojima se kaznena djela događaju pruža ekološka kriminologija (Andresen, 2014.). Pritom se oslanja na teoriju rutinskih aktivnosti (Cohen i Felson, 1979.), teoriju racionalnog izbora (Cromwell i sur., 1991.) i teoriju kriminalnog obrasca (Brantingham i Brantingham, 1995.). Iako se unekoliko razlikuju, one se u suštini fokusiraju na mogućnosti ili prilike za činjenje kaznenih djela, čija se primjenjivost objašnjava nastavno u tekstu. Prije svega, mehanizam počinjenja kaznenog djela podrazumijeva motiviranog i spremnog počinitelja, okolnosti koje obuhvaćaju pogodne ili privlačne mete napada, varijable mjesta i vremena te izostanak odgovarajuće socijalne kontrole koja bi mogla odvratiti potencijalnog počinitelja od činjenja kaznenog djela (teorija racionalnog izbora).

Obrasci kriminalnog ponašanja i obrasci normalnog ponašanja počinitelja kaznenih djela uzajamno se isprepliću, nadovezuju ili slijede jedan za drugim u njihovom svakodnevnom načinu života (teorija rutinske aktivnosti). Naime, svaki pojedinac tijekom života razvija vlastiti tzv. osviješteni prostor provodeći rutinske aktivnosti poput odlaska ili putovanja na posao ili školu, na mjesta za druženje, kupovinu i rekreaciju, u posjete prijateljima i slično. Jedna skupina teorija i empirijskih istraživanja unutar socijalne ekologije usredotočuje se na mjesta (teritorij) na kojima pojedinci čine svoje zločine. Naime, počinitelj ne odabire mete slučajno, već na temelju svog osviještenog prostora i niza racionalnih izbora koje donosi, s obzirom na to da delinkvent čini kazneno djelo onda kad mu je izgledna najviša dobit, a rizik je da bude uhićen najmanji (Kleemans, 1996.). Lokacije na kojima provodi kriminalnu aktivnost biti će primarno pod utjecajem počiniteljevog osviještenog prostora, koji mu je blizak ili poznat jer je o njemu dobro informiran i u njemu se osjeća sigurno. Općenito, osviješteni prostor obuhvaća četvrt u kojem osoba stanuje, mjesto i okruženje u kojem radi ili na bilo koji način djeluje, prometnice koje sve to povezuju te hodogram aktivnosti koje osoba $\mathrm{u}$ tom prostoru provodi. $\mathrm{U}$ tom smislu mjesta na kojima se događaju kaznena djela u velikoj su mjeri povezana s konkretnim obilježjima tih lokacija i mogućnostima koje one pružaju za počinjenje kaznenih djela (Butorac, 2011.).

Geografska udaljenost između počinitelja i žrtve smanjuje se zbog veće segmentiranosti života, rada, odlazaka u kupovinu, druženja i rekreacijskih aktivnosti. Pojedinci s različitom osobnom poviješću žive zajedno u mješovitim naseljima i češće putuju te se broj kontakata među ljudima koji se zapravo ne poznaju povećao tijekom posljednjih desetljeća, što, u konačnici, povećava rizik od postajanja žrtvom zločina. U tom smislu viši rizik viktimizacije imaju stanovnici gradskih područja, muškarci i maloljetnici.

Svako kazneno djelo ima počinitelja, objekt napada ili žrtvu i događa se u određeno vrijeme i na određenom mjestu ili prostoru, što obuhvaća i procese odlučivanja i izvršenja sačinjavajući tako svojevrsni obrazac kao prepoznatljivu uzajamnu povezanost subjekata, objekata, procesa i ideja (teorija kriminalnog obrasca). 


\section{Istraživačka pitanja i ciljevi}

Sukladno uvodno definiranoj svrsi istraživanja, međuodnosu stanja i kretanja kriminaliteta prije pandemije bolesti COVID-19 i novonastalih okolnosti uzrokovanih pandemijom, pretpostavka je da će se opseg i struktura različitih vrsta kaznenih djela mijenjati na različite načine i u određenom kontekstu, odnosno da će promjene $\mathrm{u}$ mobilnosti (pokretljivosti) kriminaliteta biti primarni uzrok promjena u stopama i udjelima više vrsta kaznenih djela, osobito u pandemijskoj 2020. godini. Stoga istraživačka pitanja obuhvaćaju sljedeće:

Je li pandemija bolesti COVID-19 utjecala na promjenu u opsegu, strukturi i dinamici kriminaliteta na području Hrvatske te kako je utjecala na tipologiju i obrasce činjenja kaznenih djela u odnosu na prethodno petogodišnje razdoblje?

Sukladno tome postavljeni su sljedeći ciljevi istraživanja:

- poredbeno procijeniti moguće promjene (mobilnost) opsega, strukture i dinamike ukupnog kriminaliteta i prekršaja protiv javnog reda i mira u prethodnom petogodišnjem razdoblju (2015. - 2019.) s pandemijskom 2020. godinom

- istražiti trendove, tipologiju i specifičnosti kaznenih djela općeg kriminaliteta na razini Republike Hrvatske i 20 policijskih uprava teritorijalno nadležnih za 21 županiju za referentna razdoblja.

\section{Metoda}

Ovo istraživanje obuhvaća analizu ukupnog kriminaliteta s dubinskim uvidom u opći ili konvencionalni kriminalitet u petogodišnjem razdoblju prije nastupanja pandemije bolesti COVID-19 (2015. - 2019.) u odnosu na godinu pandemije (2020.).

Empirijska analiza temelji se na sekundarnim podacima registriranih kaznenih djela i prekršaja, za tu svrhu zatraženim i dobivenim od Ministarstva unutarnjih poslova3. Prema tome, uzorak su činile kaznene i prekršajne prijave policiji tijekom referentne 2020. godine, što predstavlja posredno mjerenje kriminaliteta na određenom području (Palmer, 2020.). Podaci obuhvaćaju opseg i distribuciju kriminaliteta i prekršaja na razini Hrvatske i 20 policijskih uprava, koje pokrivaju 20 županija i Grad Zagreb. Zbog velikog broja različitih kaznenih djela, sukladno katalogu kaznenih djela kriminalističke policije, za potrebe ovog rada analizirane su dvije dominantne kategorije iz domene općeg ili konvencionalnog kriminaliteta - imovinska kaznena djela i kaznena djela s elementima nasilja na nacionalnoj te kriminalitet droga na lokalnoj razini. U svrhu dubinskog uvida prostorno su analizirani i podaci za određene policijske postaje

3 Izvori podataka: Statistički pregledi temeljnih sigurnosnih pokazatelja i rezultata rada od 2016. do 2020. godine Ministarstva unutarnjih poslova RH; Posebna izvješća MUP-a i policijskih uprava. 
(u nadležnosti sedam policijskih uprava), čiji statistički pokazatelji predstavljaju drastičan negativni ili pozitivni otklon u odnosu na predpandemijsko razdoblje, uzimajući pritom u obzir njihove urbane odnosno ruralne specifičnosti ${ }^{4}$. Dakle, za potrebe istraživanja koristile su se ekstremne vrijednosti kao indikatori osjetnog porasta ili naglog pada stope ili udjela određene vrste kaznenog djela u odnosu na prethodno razdoblje „starog normalnog“.

Nalazi uočljivih promjena na razini Republike Hrvatske i pojedinih policijskih uprava prikazani su grafovima trenda. Smisao istraživanja bio je prikazati kako novonastala pandemijska svakodnevica utječe općenito na pokretljivost ukupnog kriminaliteta, ali i na specifične segmente kriminaliteta na području Republike Hrvatske. Naime, mobilnost kriminaliteta središnja je determinanta razine prilika ili mogućnosti za činjenje kaznenih djela (Halford, Dixon i Farrell, 2020.). Promjene u mobilnosti utječu na način života i vjerojatnost interakcije između potencijalne mete napada i potencijalnih počinitelja te stupnja vjerojatnosti zaštite ili nadzora od odgovornih ili drugih osoba koje se mogu slučajno zateći na prizorištu. Za potrebe istraživanja kao varijable su korištene stopa i broj prijavljenih kaznenih djela u promatranoj godini. U istraživanju su korištene induktivna i deduktivna metoda te deskriptivna i komparativna metoda.

\section{Rezultati i rasprava}

U ovom dijelu rada elaborirani su pokazatelji stanja i kretanja ukupnog kriminaliteta, kao i trendovi i specifičnosti općeg kriminaliteta (imovinska kaznena djela i kaznena djela s elementima nasilja) na nacionalnoj i lokalnoj (županijskoj) razini prije i tijekom pandemijske krize.

\subsection{Stanje, kretanje i specifičnosti kriminaliteta u Republici Hrvatskoj (2019-2020. i 2015.-2020)}

Tijekom 2020. godine u Hrvatskoj su registrirana ukupno 53.082 kaznena djela koja se progone po službenoj dužnosti. U odnosu na prethodnu 2019. godinu kriminalitet je u manjem padu za $5,2 \%{ }^{5}$, a razlika u stopi kriminaliteta relativno je niska i iznosi samo 61 kazneno djelo manje na 100.000 stanovnika (tablica 3). Udio općeg ili konvencionalnog kriminaliteta u ukupnom kriminalitetu bez prometa iznosi 79,5\%, a odnosi se pretežito na imovinska i kaznena djela s elementima nasilja, koja su, ukupno gledano, u 2020. godini u laganom padu od 3,3\% (tablica 2).

\footnotetext{
${ }^{4}$ Sukladno Zakonu o lokalnoj i područnoj samoupravi za gradsko naselje u ovom se radu određuje veličinski prag od 10.000 stanovnika (NN 33/01, 60/01, 129/05, 109/07, 125/08, 36/09, 150/11, 19/13)

5 Statistički pregled temeljnih sigurnosnih pokazatelja i rezultata rada u 2020. godini, Zagreb: MUP https://mup.gov.hr/UserDocsImages/statistika/2021/Statisticki pregled 2020 web.pdf. pregledano 30 . travnja 2021.
} 
Tablica 1.

Poredbeni prikaz strukture ukupnog kriminaliteta 2019. - 2020.

\begin{tabular}{|c|c|c|c|}
\hline \multirow{2}{*}{ Kriminalitet } & \multicolumn{3}{|c|}{ Prijavljena kaznena djela } \\
\cline { 2 - 4 } & \multicolumn{2}{|c|}{ Broj djela } & Trend \\
$\mathbf{n y y n}$ & $\mathbf{2 0 1 9 .}$ & $\mathbf{2 0 2 0 .}$ & $-3,3$ \\
\hline Opći & 42.651 & 41.254 & $+81,8$ \\
\hline Ekstremno nasilje i terorizam & 33 & 60 & $+150,0$ \\
\hline Ratni zločini & 20 & 60 & $+6,3$ \\
\hline Organizirani & 2.044 & 2.173 & $+9,5$ \\
\hline Gospodarski & 4.137 & 4.532 & $-7,9$ \\
\hline Droga & 2.871 & 2.654 & $-59,5$ \\
\hline Kibernetički kriminalitet & 2.930 & 1.188 & $-5,1$ \\
\hline Ukupno bez prometa & 54.686 & 51.902 & $-9,8$ \\
\hline U prometu & 1.308 & 1.180 & $-5,2$ \\
\hline Ukupno & 55.994 & 53.082 & $+15,1$ \\
\hline Na štetu djece i obitelji & 6.859 & 7.895 & \\
\hline
\end{tabular}

Izvor: Statistički pregled temeljnih sigurnosnih pokazatelja i rezultata rada u 2020. godini (2021.), Zagreb: MUP

Iako nije predmetom ovog istraživanja, u strukturi kriminaliteta na nacionalnoj razini ističe se oštar pad kibernetičkog kriminaliteta za gotovo 60\% u 2020. godini, što je paradoksalno jer se pretpostavlja da su u pandemijskim uvjetima ograničenog kretanja i ostvarivanja socijalnih kontakata delinkventno ponašanje počinitelja (s više raspoloživog vremena za identifikaciju žrtve) i viktimizacija žrtve vezani uz korištenje kibernetičkog prostora i tehnologije.

S druge strane, nagli porast bilježe kaznena djela ekstremnog nasilja za 81,8\% (tablica 1). Riječ je o širokom spektru kaznenih djela od rasne i druge diskriminacije, povrede prava na okupljanje i javni prosvjed do širenja lažnih i uznemirujućih glasina te svim oblicima kaznenih djela zločina iz mržnje. U 2020. godini dominantno je kazneno djelo izazivanje nereda (23 djela u odnosu na 8 djela u 2019. ili 187,5\% više), javno poticanje na nasilje i mržnju 31 djelo u odnosu na 14 djela u 2019 ili 121,4\% više) te zločin iz mržnje, koji uključuje ukupno 87 različitih kaznenih djela počinjenih s motivom mržnje prema žrtvi. Pri tom se ističu 24 djela prijetnje ili $84,6 \%$ više u odnosu na 2019., 29 djela oštećenja tuđe stvari ili 222,2\% više, 21 djelo javnog poticanja na nasilje i mržnju ili 75\% više. Među motivima ovoga kriminaliteta dominantno su nacionalno podrijetlo (69 djela) i vjeroispovijest (8 djela). No, za razliku od prikazanih trendova kazneno djelo nasilničkog ponašanja bilježi $71 \%$ pad $^{6}$. Treba podsjetiti

${ }^{6}$ Statistički pregled temeljnih sigurnosnih pokazatelja i rezultata rada u 2020. godini, Zagreb: MUP, str. 44 i 45. https://mup.gov.hr/UserDocsImages/statistika/2021/Statisticki pregled 2020 web.pdf. Pregledano 30. travnja 2021. 
kako su se mnogi građani suočili s egzistencijalnim pitanjima zbog prekida poslovnih aktivnosti ili gubitka zaposlenja. Neki od razloga manifestacije tih oblika nasilja najvjerojatnije leže u višestrukoj deprivaciji ljudskih potreba kao što su onemogućavanje održavanja habitualnih društvenih kontakata, samoaktualizacije u privatnom i poslovnom životu, donošenja autonomnih odluka i slično.

Jednako tako, kriminalitet protiv života i tijela (ubojstva i pokušaji ubojstva) pokazuju osjetno povećanje za $25 \%$, a silovanja za čak $130 \%$ u odnosu na prethodno razdoblje (tablica 2 i slika 1). Epidemiološke mjere tijekom pandemije uvjetovale su gotovo isključivo provođenje zajedničkog obiteljskog života i rada svih članova obitelji u istom, ograničenom prostoru doma. Zbog promjene dnevne rutine i načina života ta je interakcija bila znatno intenzivnija i stoga je najvjerojatnije proizvodila frustracije, koje su katkad dovodile do eskalacije hostilnog pa i agresivnog ponašanja u interpersonalnim odnosima, što je posljedično rezultiralo fizičkim nasrtajima. Usto, službene statistike ovise o činjenici hoće li oštećeni ili žrtva prijaviti kazneno djelo da bi se kao takvo evidentiralo. Naime, cilj počinitelja tih tzv. kontaktnih kaznenih djela jest uspostaviti moć i kontrolu nad drugim osobama upotrebom sile, zastrašivanjem i manipuliranjem. Nasilnički delikti obično započinju blažim oblicima psihološkog nasilja, koje žrtva ni ne prepoznaje kao nasilje, a zatim se postupno pojačavaju u pogledu razmjera i učestalosti nakon prvog nasilnog događaja. Upravo zato najveći dio kaznenih djela silovanja, obiteljskog nasilja i kibernetičkog kriminaliteta neće biti registriran, a viktimizacijske studije u svijetu još nisu provedene (Mawby, 2020.).

Unatoč tome što kriminalitet droga na nacionalnoj razini bilježi blagi pad od 9,8\%, u 2020. godini, Karlovačka i Bjelovarsko-bilogorska županija pokazuju znatno povećanje tog kriminaliteta u rasponu od $68 \%$ do $93 \%$ u odnosu na prethodnu godinu (Slika 4). Naime, zbog uvođenja restriktivnih epidemioloških mjera diljem Europe, pa tako i u Hrvatskoj, smanjene su mogućnosti za distribuciju droga i stoga su svi sudionici u kriminalnom hijerarhijskom lancu opskrbe drogom stvorili značajne zalihe i posljedično smanjili cijene na ilegalnom tržištu droga (EMCDDA, 2020.). Prekomjerna ponuda rezultirala je većom dostupnošću jeftinih psihoaktivnih tvari visoke čistoće, što predstavlja i povećan rizik od predoziranja. U svakom slučaju, iskazana je najveća potražnja za marihuanom i to putem darkneta.

Udio imovinskih delikata iznosi 57\%, a prevagu nose krađe, teške krađe i razbojništva, koji su u odnosu na 2019. godinu u osjetnom padu za 32,1\% (svi oblici krađa) odnosno za 22,2\% (razbojništva) odnosu na 2019. godinu. Znatan pad pokazuje i kazneno djelo otuđenja motornih vozila $(31,1 \%)$ (tablica 2$)$. 
Tablica 2.

Poredbeni prikaz strukture i opsega općeg kriminaliteta 2019. - 2020.

\begin{tabular}{|c|c|c|c|}
\hline \multirow{2}{*}{ Kriminalitet po službenoj dužnosti } & \multicolumn{3}{|c|}{ Prijavljena kaznena djela } \\
\cline { 2 - 4 } & 2019. & 2020. & $\begin{array}{c}\text { Trend } \\
\%\end{array}$ \\
\hline OPĆI KRIMINALITET & 42.651 & 41.254 & $-3,3$ \\
\hline Ubojstva & 30 & 36 & $+20,0$ \\
\hline Pokušaji ubojstva & 98 & 108 & $+10,2$ \\
\hline Silovanja & 73 & 168 & $+130,1$ \\
\hline Pokušaji silovanja & 12 & 16 & $+33,3$ \\
\hline Razbojništva & 670 & 521 & $-22,2$ \\
\hline Teške krađe & 11.579 & 9.521 & $-17,8$ \\
\hline Otuđenja motornih vozila & 940 & 648 & $-31,1$ \\
\hline
\end{tabular}

Izvor: Statistički pregled temeljnih sigurnosnih pokazatelja i rezultata rada u 2020. godini (2021), Zagreb: MUP

Za razliku od jedva primjetnog silaznog trenda kriminaliteta u Hrvatskoj, prva istraživanja o kriminalitetu u desetak većih gradova u SAD-u, Velikoj Britaniji i Kanadi u razdoblju pandemije ukazala su na sveopći drastičan pad stope kriminaliteta (Palmer, 2020.; Shayegh i Malged, 2020.; Felson, Jiang i Xu, 2020.). Prema Campedelli i sur. (2020.) te Lum, Maupin i Stolz (2020.), silazni trend bilježe razbojništva $(20$ - 30\%), krađe $(21 \%)$ i tjelesna ozljeda (11\%), što se uglavnom podudara s udjelima tih kaznenih djela u Hrvatskoj (tablica 2). Gotovo u svim državama svijeta teške krađe bilježe silazni trend (Ashby, 2020a.; Payne i sur., 2020.; Halford i sur, 2020.). Nasuprot tome, švedski istraživači Gerell, Kordell i Kindgreen (2020.) ustanovili su pad od samo 9\% ukupnog prijavljenog kriminaliteta unatoč blagim restriktivnim mjerama u javnom prostoru. Smanjila se samo incidencija provalnih krađa za $23 \%$ i džepnih krađa za $61 \%$, dok su udjeli razbojništava i kriminalitet droga ostali na istoj razini. Halford i sur. (2020.) također potvrđuju silazni trend krađa, razbojništava i otuđenja motornih vozila za $50 \%$ te $40 \%$ manje prijava za obiteljsko nasilje.

Kazneno djelo širenja i prenošenja zaraznih bolesti bilježi očekivani nagli, apsolutni rast u 2020. godini (slika 1). Naime, u prethodnom petogodišnjem razdoblju „starog normalnog" registrirano je samo jedno kazneno djelo, tijekom pandemijskog razdoblja 76 kaznenih djela u 2020., a samo u prva dva mjeseca 2021. godine zabilježeno je 56 kaznenih djela. U istom razdoblju prekršajno je evidentirano i 3.680 slučajeva prema Zakonu o zaštiti pučanstva od zaraznih bolesti

7 Zakon o zaštiti pučanstva od zaraznih bolesti, Narodne novine 79/07, 113/08, 43/09, 130/17, 114/18, 47/20, 134/20. 
Slika 1.

Grafički prikaz broja prijavljenih silovanja, kaznenih djela širenja i prenošenja zarazne bolesti te kaznenih djela iz domene terorizma i ekstremnog nasilja na području RH po godinama za razdoblje 2015. - 2020.

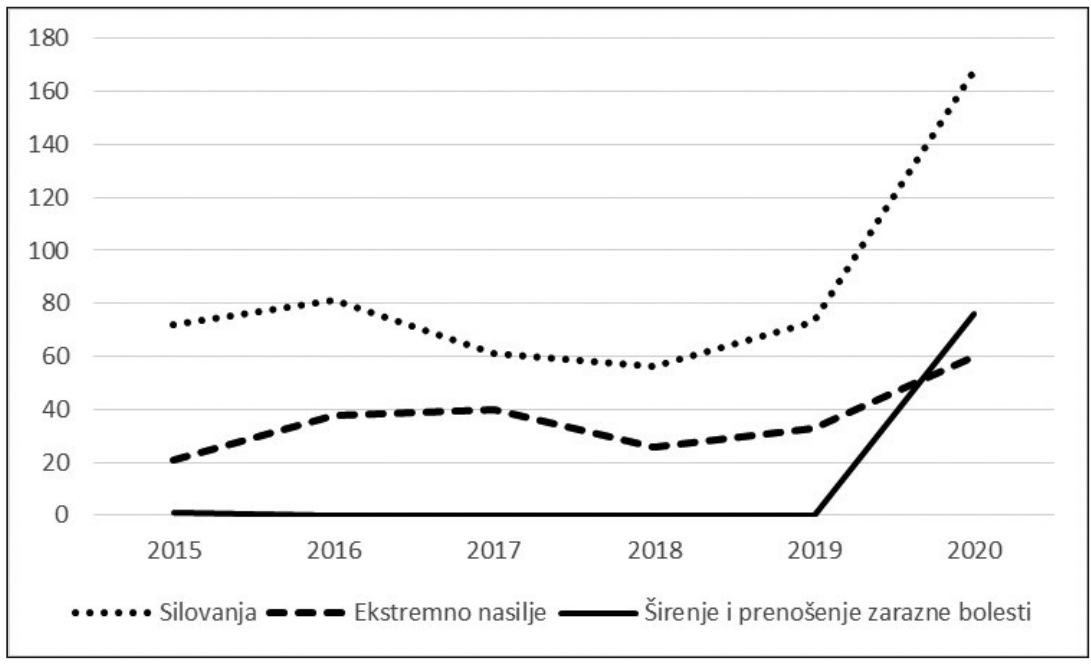

Izvor: Statistički pregled temeljnih sigurnosnih pokazatelja i rezultata rada u 2020. godini (2021.), Zagreb: MUP

U svijetu se očekivao porast prijava za obiteljsko nasilje i kaznena djela na štetu djece u pandemijskoj godini zbog svakodnevnih i intenzivnih interakcija članova obitelji u domu i stoga brojnih prilika koje nasilnici imaju za napad na žrtve (Farrell i Tilley, 2020.), što se upravo pokazalo na primjeru situacije u Hrvatskoj, gdje kriminalitet na štetu djece i obitelji pokazuje neprekidan linearni trend od 2018. godine s porastom od 15,1\% u odnosu na prethodnu 2019. godinu (tablica 1 i slika 2). Međutim, u svijetu su ti delikti nasilja pretežito ostali na istoj razini ili su čak smanjeni do $40 \%$. Farrel i Tilley (2020.) smatraju da su neki od razloga za takav ishod ublažen izvanjski pritisak na članove obitelji, manje konzumiranje alkohola u barovima i kraće radno vrijeme. S druge strane, porast obiteljskog nasilja kao oblik kontrole i zastrašivanja slabijih članova obitelji zabilježeni su u Kini, SAD-u i Francuskoj (Godin, 2020.; Wanqing, 2020.), gdje su vlade omogućile skloništa za žrtve obiteljskog nasilja u hotelima (Godin, 2020.; Rozman, 2020.). Posebno treba istaknuti fenomen tzv. tamne brojke realiziranih, ali neprijavljenih kaznenih djela zbog stalne prisutnosti nasilnika i nemogućnosti prijavljivanja od žrtve, odnosno nemogućnosti prostornog odvajanja žrtve od nasilnika u zadanom, prisilnom obiteljskom okruženju. Treba dodati da se, osim kaznenih djela obiteljskog nasilja, i spolni delikti, u pravilu, rijetko prijavljuju represivnim tijelima, stoga se taj trend ne može objektivno protumačiti. Riječ je o zabrinjavajućem porastu broja žrtava kojima pomoć nije dostupna zato što nema službeno registriranih prijava. 
Slika 2.

Grafički prikaz broja prijavljenih kaznenih djela na štetu djece i obitelji te kaznenih djela iz domene zlouporabe droga na području RH po godinama za razdoblje 2015. - 2020.

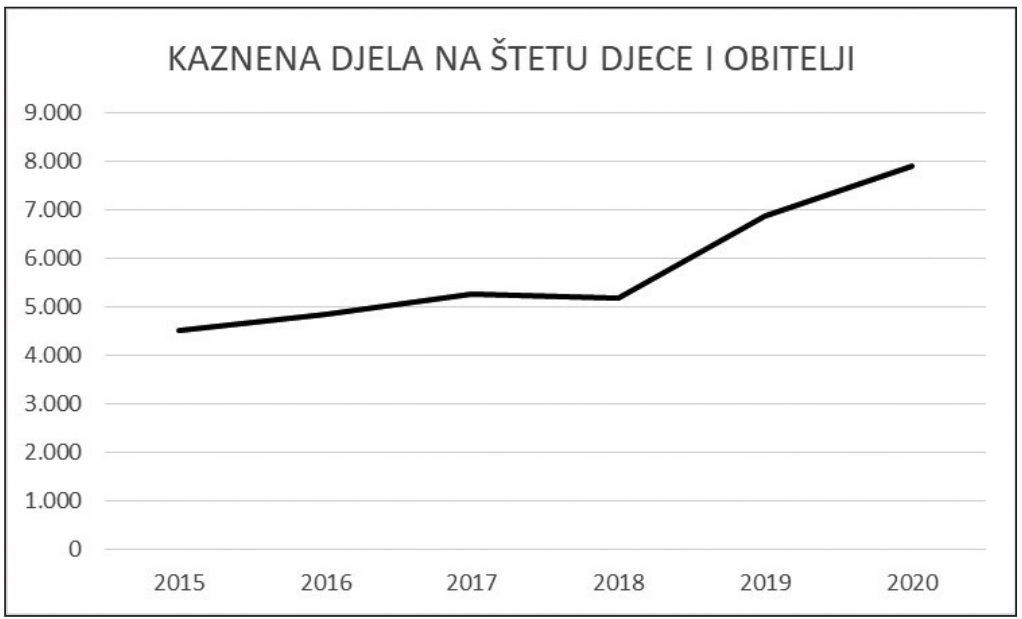

Izvor: Statistički pregled temeljnih sigurnosnih pokazatelja i rezultata rada u 2020. godini (2021.), Zagreb: MUP

\subsection{Stanje, kretanje i specifičnosti kriminaliteta na lokalnoj razini u Republici Hrvatskoj (2019.-2020. i 2015.-2020.)}

Premda je razlika u stopi ukupnog kriminaliteta 2020. godine u odnosu na predpandemijsku godinu relativno niska (-61), u tablici 3 uočljiv je njegov ekstreman pad na području Istarske, Zadarske, Šibensko-kninske i Koprivničko-križevačke županije (208 272). Taj oštar silazni trend odnosi se na imovinski kriminalitet (teške krađe, razbojništva i otuđenje motornog vozila) u rasponu od $28-44 \%$, kibernetički kriminalitet između 17 i $79 \%$ te kriminalitet droga, koji je smanjen za $18-36 \%$. Određena kaznena djela s elementima nasilja, kao što su silovanje i pokušaj ubojstva, značajno su porasla u opsegu od 50 - 133\% (Ministarstvo unutarnjih poslova RH, 2021.).

Tablica 3.

Stope kriminaliteta za RH i odabrane PU u razdoblju 2020. - 2019.

\begin{tabular}{|c|c|c|c|c|c|}
\hline \multirow{2}{*}{ PU - županija } & \multirow{2}{*}{ Broj stanovnika } & \multirow{2}{*}{$\begin{array}{l}\text { Broj kaznenih } \\
\text { djela }\end{array}$} & \multicolumn{2}{|c|}{$\begin{array}{c}\text { Broj kaznenih djela na } 100000 \\
\text { stanovnika }\end{array}$} & \multirow{2}{*}{$\begin{array}{c}\text { Razlika broja } \\
\text { k.d. na } 100 \\
000 \text { stanovnika } \\
2020 .-2019 \text {. }\end{array}$} \\
\hline & & & 2019. & 2020. & \\
\hline $\begin{array}{l}\text { Republika } \\
\text { Hrvatska }\end{array}$ & 4.065 .253 & 51.902 & 1.338 & 1.277 & -61 \\
\hline PU istarska & 209.573 & 3.432 & 1.910 & 1.638 & -272 \\
\hline $\begin{array}{l}\text { PU sisačko- } \\
\text { moslavačka }\end{array}$ & 145.904 & 2.144 & 1.191 & 1.469 & +278 \\
\hline
\end{tabular}




\begin{tabular}{|c|c|c|c|c|c|}
\hline & & \multirow{2}{*}{ PU - županija } & Broj stanovnika & Broj kaznenih & \multicolumn{2}{|c|}{$\begin{array}{c}\text { Broj kaznenih djela na } 100 \text { 000 } \\
\text { djela }\end{array}$} & $\begin{array}{c}\text { Razlika broja } \\
\text { k.d. na 100 }\end{array}$ \\
\cline { 4 - 6 } & & $\mathbf{2 0 1 9 .}$ & $\mathbf{2 0 2 0 .}$ & $\begin{array}{c}\text { 000 stanovnika } \\
\text { 2020. - 2019. }\end{array}$ \\
\hline $\begin{array}{c}\text { PU šibensko- } \\
\text { kninska }\end{array}$ & 99.210 & 1.628 & 1.849 & 1.641 & -208 \\
\hline PU zadarska & 168.213 & 2.966 & 2.005 & 1.763 & -241 \\
\hline $\begin{array}{c}\text { PU koprivničko- } \\
\text { križevačka }\end{array}$ & 106.367 & 1.044 & 1.196 & 982 & -214 \\
\hline $\begin{array}{c}\text { PU vukovarsko- } \\
\text { srijemska }\end{array}$ & 150.985 & 2.069 & 1100 & 1370 & +270 \\
\hline
\end{tabular}

Izvor: Statistički pregled temeljnih sigurnosnih pokazatelja i rezultata rada u 2020. godini (2021.), Zagreb: MUP

S druge strane, snažan porast stope kriminaliteta $(270$ - 278\%) dogodio se na području Sisačko-moslavačke i Vukovarsko-srijemske županije, gdje je zabilježen porast obiteljskog nasilja i kriminaliteta na štetu djece od 14 do $40 \%$ te kibernetičkog kriminaliteta u rasponu od 67 do 127\%. Najvjerojatnije su žene i djeca bili uskraćeni ili ograničeni u dobivanju profesionalne pomoći ili pomoći članova šire obitelji (Van Gelder i sur., 2020.). Istraživači navode da su tom obliku nasilja u velikoj mjeri pridonijeli nezaposlenost, smanjene plaće, odnosno ekonomski stres uz emocionalnu nesigurnost i društvenu izolaciju kao rizični faktori koji su značajno pogoršali situaciju (Godin, 2020.).

Slika 3.

Grafički prikaz broja prijavljenih kaznenih djela na štetu djece i obitelji na području Splitsko-dalmatinske, Primorsko-goranske te Sisačko-moslavačke županije po godinama u periodu 2015. - 2020.

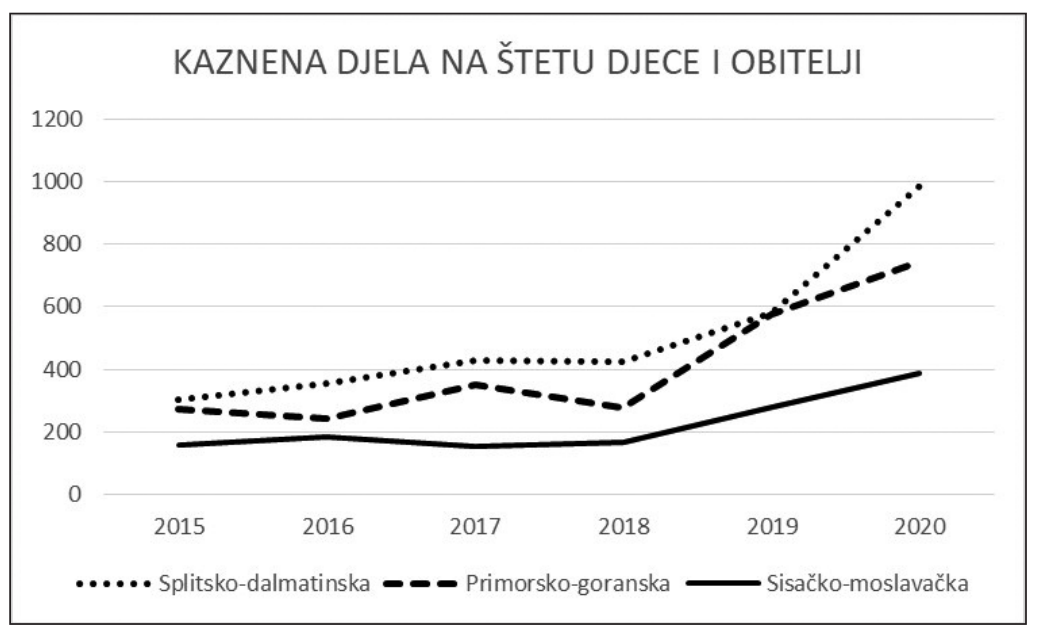

Izvor: Posebna izvješća MUP-a i policijskih uprava Splitsko-dalmatinske, Primorsko-goranske te Sisačkomoslavačke (2021.)

Kada je riječ o kaznenim djelima na štetu djece i obitelji u odnosu na 2019. godinu, 
slika 3 prikazuje nagli trend porasta u referentnom razdoblju na području splitskodalmatinske županije (71\%), specifično na području Brača, Omiša, Sinja i Vrgorca bilježi se višestruki oštar porast te vrste kriminaliteta u odnosu na 2019. godinu. Ponešto blaža tendencija kontinuiranog povećanja kaznenih djela u cijelom promatranom razdoblju iz te domene uočava se u Sisačko-moslavačkoj županiji, s porastom od 39\% u odnosu na prethodnu 2019. godinu. Promatrajući područja s ruralnim karakterom uočava se snažna tendencija povećanja kaznenih djela na štetu djece i obitelji na području Novske, Gline, Hrvatske Kostajnice i Dvora, u rasponu od 93\% do $1.300 \%$ u odnosu na 2019. godinu. Prisutan je neprekidan uzlazni trend incidencije tog kriminaliteta i na području Primorsko-goranske županije od 2018. godine, a u pandemijskoj 2020. godini porastao je za 29,3\%. Riječ je svakako o fenomenu koji bi trebalo detaljnije istražiti i iznaći mehanizme za pomoć i podršku žrtvama u ruralnim sredinama koje imaju kronični nedostatak stručnjaka, kako u javnom sektoru tako i u organizacijama civilnog društva.

Slika 4.

Grafički prikaz broja prijavljenih kaznenih djela iz domene zlouporabe droga na području Karlovačke i Bjelovarsko-bilogorske županije po godinama za razdoblje 2015. - 2020.

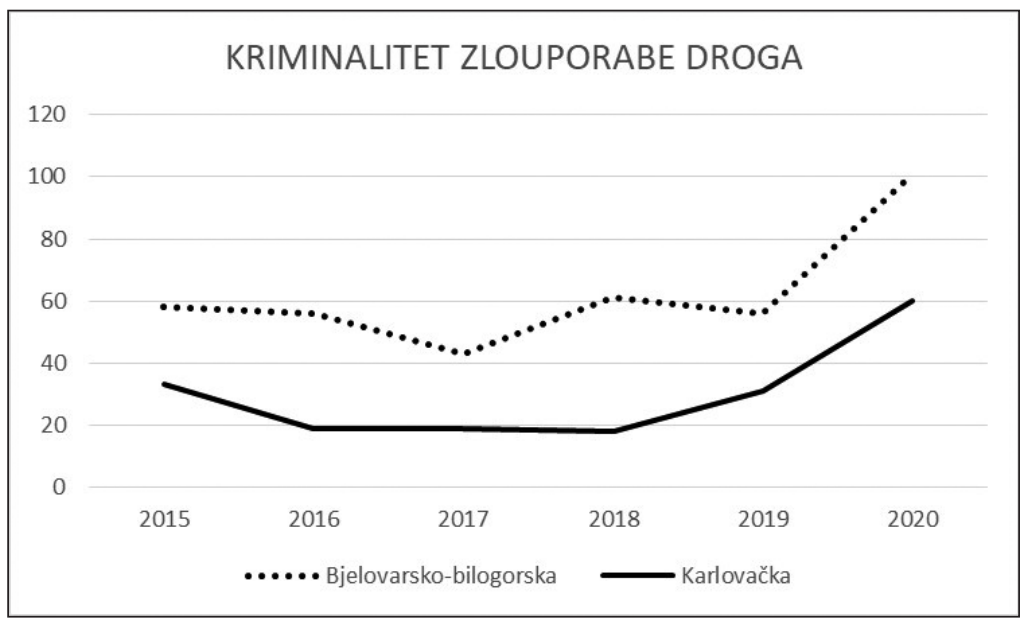

Izvor: Posebna izvješća MUP-a i policijskih uprava Karlovačke i Bjelovarsko-bilogorske županije (2021.)

Uspoređujući kriminalitet zlouporabe droga s ostalim županijama, najzapaženiji porast kriminaliteta zlouporabe droga zabilježen je u 2020. godini na području Karlovačke $(93,5 \%)$ i Bjelovarsko-bilogorske županije $(80 \%)$ u odnosu na prethodnu godinu. Bez obzira na to što je riječ o pretežno ruralnom stanovništvu u navedenim županijama, danas su droge široko dostupne na popularnom internetskom kriminalnom tržištu dubokog weba (dio interneta čiji sadržaj nije dostupan putem konvencionalnih mrežnih pretraživača), odnosno darkneta, osobito tijekom pandemije bolesti COVID-19 zahvaljujući kombinaciji tehnologija koje nude veću anonimizaciju prodavača i kupaca. 
Slika 5.

Grafički prikaz broja prijavljenih prekršaja protiv javnog reda i mira na području Istarske, Sisačkomoslavačke i Zadarske županije za razdoblje 2014. - 2020.

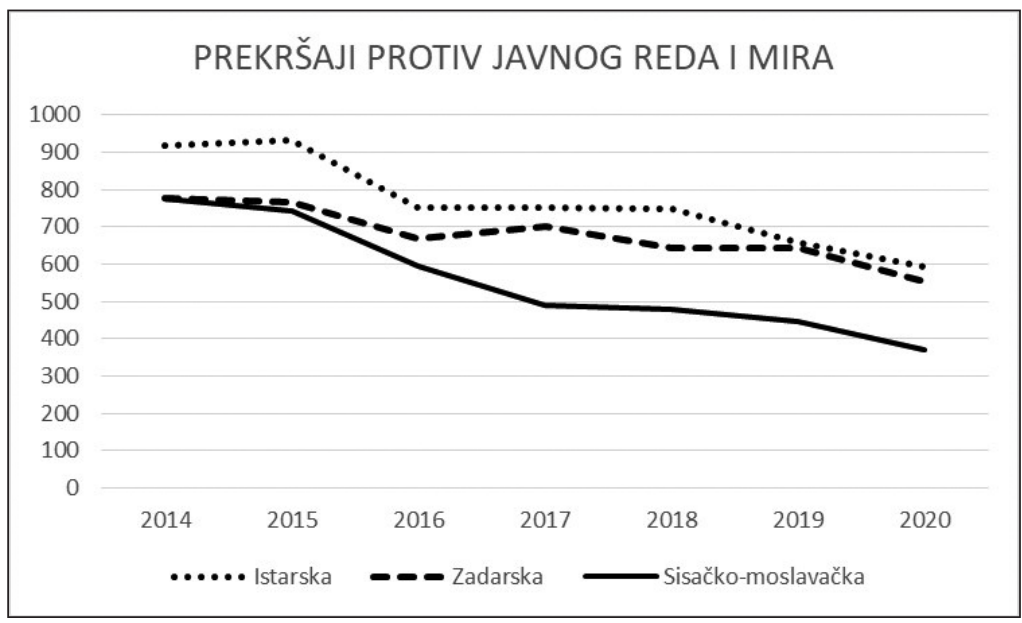

Izvor: Posebna izvješća MUP-a i policijskih uprava Istarske, Sisačko-moslavačke i Zadarske (2021.)

U strukturi prekršaja u 2020. godini približno jedna četvrtina $(26,4 \%)$ odnosi se na javni red i mir, a visokog su udjela i prekršaji u području nasilja u obitelji, zlouporabe opojnih droga i drugi. Prostorna distribucija i rasprostranjenost prekršaja odgovara pokazateljima veličine policijskih uprava, ali u usporedbi 2020. s 2019. godinom zamjetni su različiti trendovi u pojedinim policijskim upravama. Tako, primjerice, Policijska uprava (nastavno PU) istarska bilježi najveći pad od 40,89\%, PU krapinsko-zagorska 28,01\% te PU dubrovačko-neretvanska i PU bjelovarsko-bilogorska oko 20\%. S druge strane, PU karlovačka i PU splitsko-dalmatinska bilježe najveći porast od 16,46 odnosno $13,23 \%$. Ti relativno oprečni trendovi ne mogu se objasniti izvan konteksta i na manifestnoj razini, stoga zavrjeđuju dubinsku empirijsku analizu, no trend značajnijeg pada broja prekršaja u određenim županijama može se povezati s ograničenjem kretanja građana u javnom prostoru, posebice u ugostiteljskim objektima, na cestama i sličnim lokacijama koje su ranije imale povećanu incidenciju.

Slika 5 pokazuje stanoviti kontinuirani silazni trend prijavljenih prekršaja protiv javnog reda i mira i ostalih prekršaja na području Istarske $(40,1 \%)$, Sisačko-moslavačke $(14,7 \%)$ i Zadarske županije (15,8\%) od 2014. godine nadalje. U odnosu na 2019. godinu ti su udjeli znatno manji i kreću se u rasponu od 10 do 17\%. Navedeni su pokazatelji relativno neočekivani budući da se predmnijevalo kako će pandemijska situacija tijekom 2020. godine značajno reducirati slobodno kretanje i okupljanje građana na otvorenim prostorima, tim više što su na snazi bile i epidemiološke mjere djelomičnog zatvaranja ugostiteljskih objekata. U svijetu su, također, zabilježena kršenja pravila javnog okupljanja (Simcox, 2020.; Robinson, 2020.; Willshoe, 2020.). 
U konačnici se može ustvrditi kako ograničavanje kretanja i putovanja utječe na različite načine na mobilnost pojedinih vrsta kaznenih djela (Farrell i Tilley, 2020.). Primjerice, više zajednički provedenog vremena u domu i zabilježeni nagli porast distribucije alkoholnih pića u maloprodaji do 35\% (Rak Šajn, 2021.) najvjerojatnije generiraju interpersonalne konflikte, odnosno obiteljsko nasilje i zlostavljanje djece jer su, u pravilu, potencijalni počinitelji roditelji ili skrbnici djece. Istodobno je u tom kontekstu manja mogućnost za činjenje teških krađa provalom u domove ili stanove. Nadalje, ograničenje rada određenih trgovina, smanjena učestalost putovanja, manja fluktuacija ljudi u javnom prostoru uvjetuju manju incidenciju kaznenih djela u javnom prijevozu. U svijetu se pokazalo da su rad od kuće i znatna duljina provođenja slobodnog vremena u zatvorenom prostoru vjerojatno utjecala i na veću pojavnost kibernetičkog kriminaliteta (Mitchel Miller i Blumstein, 2020; Halford, Dixon i Farrell, 2020; Mawby, 2020), za razliku od Hrvatske, gdje je najvjerojatnije izostalo proaktivno djelovanje policije u otkrivanju ove vrste kriminaliteta. Zatvaranjem ugostiteljskih objekata konzumiranje alkohola bilo je gotovo nedostupno, što je rezultiralo padom broja prekršaja protiv javnog reda i mira. Slijedom navedenog, opseg i struktura različitih vrsta kaznenih djela mijenjat će se na različite načine i u određenom kontekstu.

\section{Zaključak}

Na temelju pregleda spoznaja recentne literature o stanju i kretanju kriminaliteta prije i poslije nastupanja pandemijske krize te rezultata dobivenih predmetnim istraživanjem u ovom radu može se ustvrditi da je gotovo svaka društvena zajednica tijekom pandemijskog kriznog razdoblja bila prilično dezorganizirana, a društveni utjecaji i međuljudski odnosi ugroženi zbog nametnute prekinute ili smanjene interakcije i uobičajene komunikacije. Anomija, stres i anksioznost imali su utjecaj na većinu ljudi zbog neizvjesne fizičke i financijske budućnosti. Odvraćanje od činjenja kaznenih djela kao punitivni odgovor bio je usporen ili je izostao jer su sudovi bili djelomično zatvoreni, u mnogim državama zatvorenici su bili otpušteni, a policija je primarno bila zadužena za onemogućavanje kontakata u javnom prostoru i stoga u određenoj mjeri reducirala svoju otkrivačku djelatnost, što implicira povećanje tamne brojke neotkrivenog kriminaliteta. Pored toga, okolnosti pandemije uvjetovale su i djelomični nedostatak policijskih službenika zbog samoizolacije ili zaraženosti virusom.

Istraživanja u svijetu i Hrvatskoj pokazuju kako postoje drastične varijacije u stopama kriminaliteta, ali ne u svim kategorijama kaznenih djela, mjestima i vremenskom okviru. Tome je neizostavno pridonijela mjera zatvaranja kao varijabla koja je uzrokovala drastičnu promjenu svakodnevnih, uobičajenih rutinskih aktivnosti gotovo cjelokupne populacije, pa tako i počinitelja kaznenih djela, koji racionalno biraju mjesto, vrijeme i objekt napada. Drugim riječima, prilike i mjesta za susret počinitelja i meta napada bile su ograničene, što je gotovo svugdje u svijetu i kod nas rezultiralo relativno značajnim padom imovinskog kriminaliteta. Prema tome, okolnosti krize uzrokova- 
ne pandemijom bolesti COVID-19 prirodno su vodile u odvijanje kvazinasumičnog kontroliranog pokusa (Stickle i Felson, 2020.). Središnje je pitanje za buduća istraživanja utvrditi determinante oštrog pada kriminaliteta i, posljedično, što se može naučiti iz ovog iskustva kako bismo ubuduće mogli utjecati na smanjenje kriminaliteta i osnaživanje potencijalnih žrtava.

Važno je naglasiti kako se određene vrste kaznenih djela poslovično manje prijavljuju policiji od ostalih, poput interpersonalnog, odnosno obiteljskog nasilja i kaznenih djela na štetu djece, što je bilo posebno izraženo u svijetu tijekom pandemije. U tom pogledu Hrvatska predstavlja iznimku budući da bilježi značajan porast svih nasilnih delikata. Treba napomenuti kako još uvijek nije poznato koji su učinci pandemije bolesti COVID-19 na pojavnost nasilja ni koje su vrste intervencija najprikladnije za njegovo sprječavanje u tom kontekstu, uzimajući u obzir kako nasilje samo po sebi predstavlja pandemiju (Krug, Mercy, Dahlberg i Zwi, 2002.; Devries i sur., 2013.; Fulu, Jewkes, Roselli i Garcia-Moreno, 2013.). Iz navedenih razloga potrebno je provesti viktimizacijske studije koje bi pružile precizan i dubinski uvid u opseg i rasprostranjenost tzv. kriminaliteta „bez žrtava“.

Kada je riječ o prognozi kriminaliteta, više zabrinjavaju dugoročne posljedice pandemije zbog povećanja stope nezaposlenosti, siromaštva i drugih situacijskih faktora „novog normalnog“". Stoga je posve neizvjesno hoće li se opseg i struktura kriminaliteta vratiti na predpandemijsko razdoblje ili će biti reducirani, odnosno hoće li se prilagoditi novonastalim okolnostima u obliku prostornog premještanja kriminaliteta na druga globalna ili lokalna područja promjenom modusa operandi. Slijedom navedenog, okvirno bi se mogle klasificirati tri kategorije potencijalnih počinitelja u budućnosti. Neki od njih, osobito specijalizirani počinitelji, mogli bi odustati od kažnjivih djela zbog izostanka ili promjene mogućnosti ili prilika za činjenje specifičnih kaznenih djela; druga se kategorija odnosi na fleksibilne počinitelje, koji će najvjerojatnije svoju dosadašnju kriminalnu djelatnost zamijeniti drugom; treća kategorija obuhvaća regrutiranje novih počinitelja, koji će vjerojatno koristiti nove dostupne mogućnosti za činjenje kaznenih djela. Stoga će promjena obrazaca u činjenju kaznenih djela i izboru kriminalne karijere počinitelja biti izazovna za buduća kvantitativna i kvalitativna istraživanja u razdoblju nakon pandemije. 


\section{Literatura}

1. Andresen, M. A. (2009). The place of environmental criminology within criminological thought, in: Andresen, M. A.; Brantinghamand, P. J. and Kinney, J. B. (Eds.). Classics in Environmental Criminology. Co-published: Burnaby, BC, SFU Publications and Boca Raton, FL, Taylor \&Francis, 5-28.

2. Ashby, M. P. J. (2020a). Changes in police calls for service during the early months of the 2020 coronavirus pandemic. https://doi.org/10.3331235/osf.io/4mcu. (Pregledano 12. siječnja 2021.)

3. Ashby, M. P. J. (2020b). Changes in police calls for service during the early months of the 2020 coronavirus pandemic. https://doi.org/10.31235/osf.io/h4mcu. (Pregledano 12. siječnja 2021.)

4. Brantingham, P. and Brantingham, P. (1995). Criminality of place. European Journal of Criminal Policy and Research, 3 (3): 5-26. https://doi.org/10.1007/ BF02242925. (Pregledano 12. siječnja 2021)

5. Butorac, K. (2011). Geografija kriminaliteta - kriminološki i kriminalistički diskursi. Policija i sigurnost, 20 (3): 363-379.

6. Campedelli, G. M.; Aziani, A., and Favarin, S. (2020). Exploring the effect of 2019-nCoV containment policies on crime: The case of Los Angeles. arXiv preprint arXiv:2003.11021.

7. Cohen-Louck, K. and Levy, I. (2020). Viruism: The need for a new term describing COVID-19 impact in context of viral victimization. Psihological Trauma Theory Research Practice and Policy. Advance online publication. International Journal of Psychology, 55 (1): 115-122. https://doi.apa.org/fulltext/2020-89386-001.html. (Pregledano 12. veljače 2021.)

8. Cromwell, P.; Olson, J. and Avary, D’A. W. (1991). Breaking and entering: An ethnographic analysis of burglary. Newbury Park, CA: Sage.

9. Devries, K. M.; Mak, J. Y.; Garcia-Moreno, C.; Petzold, M.; Child, J. C.; Falder, G.; Lim, S.; Bacchus, L. J.; Engell, R. E.; Rosenfeld, L.; Pallitto, C. (2013). The global prevalence of intimate partner violence against women. Science, 340 (6140): 1527-8.

10. Estrada, M. A. R. (2020). How COVID-19 quarantine(s) can generate poverty? https://doi.org/10.13140/RG.2.2.31546 .54729/2. Pregledano 12. veljače 2021.

11. European Monitoring Centre for Drugs and Drug Addiction (2020). COVID-19 and drugs: Drug supply via darknet markets, Lisbon. https://www.emcdda.europa. eu/system/files/publications/13042/EMCDDA report COVID19-darknet-final.pdf. (Pregledano 15. ožujka 2021.)

12. Farrell, G. and Tilley, N. (2020). Coronavirus: How crime changes during a lockdown. The Conversation. https://theconversation.com/coronavirus-howcrime-changes-during-a-lockdown-134948. (Pregledano 14. siječnja 2021.)

13. Felson, M.; Jiang, S. and Xu, Y. (2020). Routine activity effects of the COVID-19 pandemic on burglary in detroit. Crime Science, 9 (1): 1-7. 
14. Fulu, E.; Jewkes, R.; Roselli, T.; Garcia-Moreno, C. (2013). Prevalence of and factors associated with male perpetration of intimate partner violence: findings from the UN Multi-country Cross-sectional Study on Men and Violence in Asia and the Pacific. The Lancet Global Health, 1 (4): 187-207.

15. Gerell, M., Kardell, J. and Kindgren, J. (2020). Minor COVID-19 association with crime in Sweden, afive week follow up. Malmo University. https://osf.io/ preprints/socarxiv/w7gka/. (Pregledano 12. veljače 2021.)

16. Godin, M. (2020). France to house domestic abuse victims in hotels amid lockdown. Time. https ://time.com/58129 90/france-domes tic-viole nce-hotel -coron aviru s/. (Pregledano 21. rujna 2020.)

17. Halford, E.; Dixon, A. and Farrell, G. (2020). Crime and corona virus: social distancing, lockdown, and the mobility elasticity of crime. Crime Science, 9 (11): 1-12. https://doi.org/10.1186/s40163-020-00121-w. (Pregledano 12. veljače 2021.)

18. Institute For Economics and Peace (2017). Global terrorism index: Measuring and understanding impact of terrorism. http://visionofhumanity.org/app/uploads/2017/11/Global-Terrorism-Index2017.pdf. (Pregledano 12. veljače 2021.)

19. Kaplan, J.; Frias, L. and McFall-Johnsen, M. (2020). A third of the global population is on coronavirus lockdown-Here's our constantly updated list of countries locking down and opening up. Business Insider. https://www.businessinsider.com/ countries-onlockdown-coronavirus-italy-2020-3. Pregledano 12. veljače 2021.

20. Kleemans, E. R. (1996). Strategische Misdaadanalyse en Stedelijke Criminaliteit: Een toepassing van de rationele keuzebenadering op stedelijke criminaliteitspatronen en het gedrag van daders, toegespitst op het delict woninginbraak. (Strategic Crime Analysis and Urban Crime Patterns: An application of the Rational Choice Approach on Urban Burglary Patterns and Offender Behavior). Enschede, NETH: International Police Institute Twente, Faculty of Public Administration and Public Policy, University of Twente.

21. Krug, E. G.; Mercy, J. A.; Dahlberg, L. L.; Zwi, A. B. (2002). The world report on violence and health. The Lancet, 360 (9339): 1083-8.

22. Lee, V. J.; Chiew, C. J. and Khong, W. X. (2020). Interrupting transmission of COVID-19: Lessons from containment efforts in Singapore. Journal of Travel Medicine, 27 (3): 1-5. https://doi.org/10.1093/jtm/taaa039. (Pregledano 12. veljače 2021.)

23. Lum, C.; Maupin, C. and Stoltz, M. (2020). The impact of COVID-19 on law enforcement agencies (wave 1). International Association of Chiefs of Police. https://www.theiacp.org/sites/default/files/IACP-GMU\%20Survey.pdf. (Pregledano 15. siječnja 2021.)

24. Mawby, R. (2020). Coronavirus, Crime and Policing: Thoughts on the implications of the lockdown rollercoaster. European Law Enforcement Research Bulletin, 20: 13-30. https://bulletin.cepol.europa.eu/index.php/bulletin/article/ view/446/327. 
25. Ministarstvo unutarnjih poslova RH (2021a). Prikaz stanja kriminaliteta prema policijskim upravama za razdoblje 2019. - 2020. godina, KLASA:953-01/21-03/8, URBROJ: 511-01-142-21-3, od 31. ožujka 2021. Zagreb: MUP RH.

26. Ministarstvo unutarnjih poslova RH (2021b). Posebna izvješća MUP-a i policijskih uprava splitsko-dalmatinske, primorsko-goranske te sisačko-moslavačke. Zagreb: MUP RH.

27. Ministarstvo unutarnjih poslova RH (2021c). Posebna izvješća MUP-a i policijskih uprava karlovačke i bjelovarsko-bilogorske županije. Zagreb: MUP RH.

28. Ministarstvo unutarnjih poslova RH (2021d). Posebna izvješća MUP-a i policijskih uprava istarske, sisačko-moslavačke i zadarske. Zagreb: MUP RH.

29. Ministarstvo unutarnjih poslova RH (2021e). Statistički pregled temeljnih sigurnosnih pokazatelja i rezultata rada u 2020. godini. https://mup.gov.hr/UserDocsImages/statistika/2021/Statisticki pregled 2020 web.pdf. (Pregledano 10. travnja 2020.)

30. Ministarstvo unutarnjih poslova RH (2021f). Odluke Stožera civilne zaštite RH za sprječavanje širenja zaraze koronavirusom. https://civilna-zastita.gov. hr/odluke-stozera-civilne-zastite-rh-za-sprecavanje-sirenja-zaraze-koronavirusom/2304. (Pregledano 15. 5. 2021.)

31. Mitchel Miller, J. and Blumstein, A. (2020). Crime Justice \& the COVID-19 Pandemic: Toward a national research agenda. American Journal of Criminal Justice, 45 (2): 515-524. https://link.springer.com/article/10.1007/s12103-02009555-z. (Pregledano, 15. siječnja 2021.)

32. Morens, D. M.; Folkers, G. K. and Fauci, A. S. (2009). What is a pandemic? The Journal of Infectious Diseases, 200 (7): 1018-1021. https://doi. org/10.1086/644537. (Pregledano 3. ožujka 2021.)

33. Payne, J. and Morgan, A. (2020). Property Crime during the COVID-19 Pandemic: A comparison of recorded offence rates and dynamic forecasts (ARIMA) for March 2020 in Queensland, Australia. "SocArXiv de9nc, Center for Open Science. https://ideas.repec.org/p/osf/socarx/de9nc.html. (Pregledano 14.04.2021.)

34. Pietrawska, B.; Aurand, S. K. and Palmer, W. (2020). COVID-19 \& crime: CAP's perspective on crime and loss in the age of COVID-19: Los Angeles crime, 2. CAP Index. https://losspreventionmedia.com/a-perspective-on-crime-and-lossin-the-age-of-covid-19/. (Pregledano 5. ožujka 2021.)

35. Qiu, J.; Shen, B.; Zhao, M.; Wang, Z.; Xie, B.; Xu, Y. (2020). A nationwide survey of psychological distress among Chinese people in the COVID-19 epidemic: Implications and policy recommendations. BMJ General Psychiatry, 33 (2): e100213. https://doi.org/10.1136/gpsych-2020-100213. (Pregledano 3. ožujka 2021.)

36. Rak Šajn, J. (2021). Poslovni dnevnik, 26.04.2021. https://www.poslovni.hr/ hrvatska/unucici-ubrzali-badelove-linije-prodaja-rasla-35-4283907. (Pregledano 15. 5. 2021.)

37. Reyns, B. (2014). Environmental criminology: Evolution, theory and practice. New York: Routledge. 
38. Robinson, J. (2020). Shocking moment fist fight breaks out on packed London train 'over passenger not wearing a face mask. MailOnline, 11 August. https:// www.dailymail.co.uk/news/article-8615941/Shocking-moment-fist-fightbreaks-packed-London-train-face-mask.html. (Pregledano 15. siječnja 2021.)

39. Rozman H. (2020). Letters to the Editor: How L. A.'s hotel industry is stepping up in the COVID-19 crisis. Los Angeles Times. https://www.latimes.com/ opinion/story/2020-04-12/hotel-industry-is-stepping-up-in-the-covid-19. (Pregledano 12. veljače 2021.)

40. Shayegh, S. and Malpede, M. (2020). Staying Home Saves Lives, Really! In Staying home saves lives, really!. RFF-CMCC European Institute on Economics and the Environment. https://doi.org/10.2139/ssrn.3567394. (Pregledano 3. ožujka 2021.)

41. Simcox, M. 2020. Fight breaks out on plane to Ibiza after two 'drunken and unruly English passengers' refused to wear face masks on KLM flight from Amsterdam. MailOnline, 2 August. https://www.dailymail.co.uk/news/article-8585439/Fight-breaks-KLM-plane-Ibiza-two-passengers-refused-wear-facemasks.html. (Pregledano 7. siječnja 2021.)

42. Stickle, B. and Felson, M. (2020). Crime rates in a pandemic: the largest criminological experiment. American Journal of Criminal Justice, 45: 525-536. https:// link.springer.com/article/10.1007/s12103-020-09546-0. Pregledano 21. siječnja 2021.

43. Sun, L.; Sun, Z.; Wu, L.; Zhu, Z.; Zhang, F.; Shang, Z.; Jia, Y.; Gu, J.; Zhou, Y.; Wang, Y.; Liu, N.; Liu, W. (2020). Prevalence and risk factors of acute posttraumatic stress symptoms during the COVID-19 outbreak in Wuhan, China. medRxiv. Advance online publication. https://doi.org/10.1101/2020.03.06.200 32425. (Pregledano 12. veljače 2021.)

44. United Nations. (1985). General Assembly resolution 40/34. Declaration of Basic Principles of Justice for Victims of Crime and Abuse of Power. https://www. ohchr.org/en/professionalinterest/pages/victimsofcrimeandabuseofpower.aspx. Pregledano 7. siječnja 2021.

45. United Nations (2020). World Drug Report 2020 (United Nations publication, Sales No. E.20.XI.6). https://wdr.unodc.org/wdr2020/. Pregledano 10. travnja 2021.

46. Van Gelder, N.; Peterman, A.; Potts, A.; O’Donnell, M.; Thompson, K.; Shah. N.; Oertelt-Prigione, S. (2020). COVID-19: reducing the risk of infection might increase the risk of intimate partner violence. EClinicalMedicine, 21: 100348.

47. Wanqing, Z. (2020). Domestic violence cases surge during COVID-19 epidemic. Sixth Tone. https://www.sixthtone.com/news/1005253/domestic-violence-cases-surge-during-covid-19-epidemic. (Pregledano 12. rujna 2020.)

48. Watkins, J. (2020). Preventing a COVID-19 pandemic. British Medical Journal (Clinical Research Ed.), 810 (1-2). https://doi.org/10.1136/bmj .m810. (Pregledano 12. siječnja 2020.) 
49. Willsher, K. (2020). Man attacked in Paris launderette for asking customer to wear mask. Guardian, 4 August. www.theguardian.com/world/2020/ aug/04/man-attacked-in-paris-launderette-for-asking-customer-to-wear-mask. (Pregledano 12. siječnja 2021.)

50. World Health Organization (2020). WHO Director-General's opening remarks at the media briefing on COVID-19 - 11 March 2020. https://www.who.int/director-general/speeches/detail/who-director-general-s-opening-remarks-at-themedia-briefing-on-covid-19---11-march-2020. (Pregledano 12. veljače 2021.)

51. Zakon o sustavu civilne zaštite, Narodne novine 82/2015, 118/2018 i 31/2020, NN 20/2021.

52. Zakonu o zaštiti pučanstva od zaraznih bolesti, Narodne novine 79/07, 113/08, 43/09, 130/17, 114/18, 47/20, 134/20. 


\title{
Crime in the COVID-19 Pandemic Atmosphere in Croatia
}

\author{
Ksenija Butorac \\ Ministry of the Interior, Police University College, Zagreb, Croatia \\ e-mail:ksenija.butorac@gmail.com \\ Davor Solomun \\ Ministry of the Interior, Police University College, Zagreb, Croatia \\ e-mail:dsolomun@fkz.hr
}

\begin{abstract}
This research includes an analysis of total crime with a detailed insight into common or conventional crime in the five-year period before the onset of the COVID-19 pandemic (20152019) compared to the year of the COVID-19 pandemic (2020). Empirical analysis is based on secondary data of registered crimes and misdemeanors for this purpose requested and obtained from the Croatian Ministry of Interior, which is an indirect measurement of crime in a particular area (Palmer, 2020). The problem of exploratory research in this paper is the acquisition of new cognition about possible changes in the scope, structure and dynamics of crime and the typology and patterns of police registered crimes and offences in the pandemic crisis period, compared to the previous five years in Croatia. The obtained results are observed through the applicability of theoretical concepts of environmental criminology in explaining the change of trends in typology and patterns of criminal and deviant behavior. The purpose of the research was to show how the emerging pandemic influences everyday life and affects the mobility of overall crime in general, but also the specific segments of crime in the Republic of Croatia and individual police directorates.
\end{abstract}

Key words: COVID-19, common crime, property crimes, violent crimes, environmental criminology. 